Provided for non-commercial research and education use. Not for reproduction, distribution or commercial use.

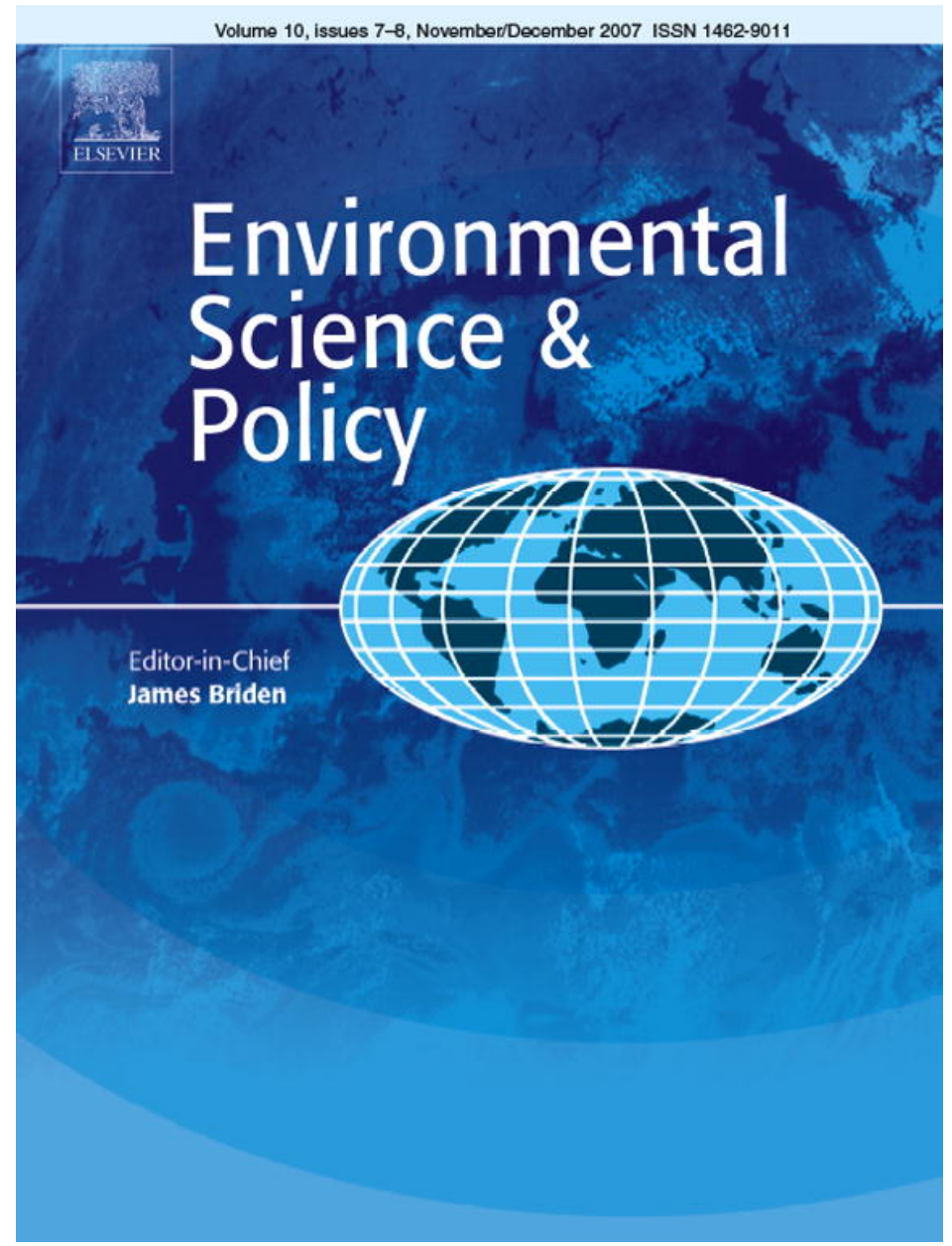

This article was published in an Elsevier journal. The attached copy

is furnished to the author for non-commercial research and education use, including for instruction at the author's institution, sharing with colleagues and providing to institution administration.

Other uses, including reproduction and distribution, or selling or licensing copies, or posting to personal, institutional or third party websites are prohibited.

In most cases authors are permitted to post their version of the article (e.g. in Word or Tex form) to their personal website or institutional repository. Authors requiring further information regarding Elsevier's archiving and manuscript policies are encouraged to visit: 


\title{
Review
}

\section{Widening the scope of policies to address climate change: directions for mainstreaming}

\author{
M.T.J. Kok ${ }^{a, *}$, H.C. de Coninck ${ }^{b}$ \\ ${ }^{a}$ MNP, Netherlands Environmental Assessment Agency, P.O. Box 303, 3720 AH Bilthoven, The Netherlands \\ ${ }^{\mathrm{b}}$ Energy research Centre of the Netherlands (ECN) Policy Studies, P.O. Box 37154, 1030 AD Amsterdam, The Netherlands
}

\section{A R T I C L E I N F O}

Published on line 27 September 2007

\section{Keywords:}

Climate change

Mainstreaming

Mitigation

Adaptation

Post-2012 climate policy

Inter-linkages

\begin{abstract}
A B S T R A C T
Both mitigation of and adaptation to climate change require actions to be taken in many sectors of society, but so far this is hardly happening. This paper suggests possibilities for widening climate change policy by strengthening inter-linkages between climate policies and various relevant policy areas to mainstream climate change concerns. It argues that, if these inter-linkages can be strengthened and policy coherence is improved, the effectiveness of climate policy can be enhanced while also supporting these other policy areas. The contention in this paper is that improved policy coherence and mainstreaming requires climate policies to go beyond the UNFCCC framework to realise its full potential and to better deal with possible trade-offs. The potential benefits in the policy domains of poverty reduction, rural development and agriculture, disaster management, energy security, air quality and trade, and finance are examined, and the institutional and organisations linkages highlighted. Finally, opportunities for mainstreaming are identified to make better use of possible synergies between climate and related policy areas.
\end{abstract}

(C) 2007 Published by Elsevier Ltd.

\section{Introduction}

There is ample evidence now that anthropogenic climate change poses serious threats to development (IPCC, 2007). Despite international agreement, laid down in the United Nations Framework Convention on Climate Change (UNFCCC, 1992) that dangerous human interference with the climate system should be prevented, climate policy faces many challenges (see amongst others Barrett, 1998; Victor, 2001). One of them is that many climate-relevant decisions continue to be taken in different policy areas with little or no regard to climate change. Both mitigation of and adaptation to climate change require actions in many sectors of society, but climate change concerns are so far hardly integrated in the decisionmaking in those sectors. Most analyses of post-2012 climate policy so far have focussed on the design and stringency of the post-2012 agreements within the UNFCCC or alternatives to the UNFCCC and its Kyoto Protocol (see e.g. Aldy et al., 2003; Höhne, 2005). This paper ${ }^{1}$ aims to assess the inter-linkages between climate change policy and a number of other policy domains and the opportunities and challenges for mainstreaming climate change therein (Huq et al., 2004; Huq and Reid, 2004). The policy domains of poverty reduction, rural development and agriculture, disaster management, energy security, air quality and trade and finance are examined for such inter-linkages.

\footnotetext{
* Corresponding author. Tel.: +31 30 2743717; fax: +31 302744464 .

E-mail address: marcel.kok@mnp.nl (M.T.J. Kok).

1 This paper is to a large extent based on the report "Beyond Climate. Options for broadening climate policy" (Kok and Coninck, 2004). It has also benefited from the outcomes of the Development and Climate programme (Kok et al., 2006). 1462-9011/\$ - see front matter (C) 2007 Published by Elsevier Ltd. doi:10.1016/j.envsci.2007.07.003
} 
The contention in this paper is that the effectiveness of climate change policies can be enhanced by mainstreaming climate change in other policy areas. Establishing appropriate linkages between functionally linked issues enhances the opportunities for problem solving and can increase the efficiency and effectiveness of policy making. Realisation of this potential, this paper argues, requires climate policy makers to widen their scope and go beyond the UNFCCC framework. This paper, hence, explores the possibilities to widen climate change policy by providing possible directions for mainstreaming and establishing institutional and organizational inter-linkages between climate change policy and a number of relevant policy areas (Asselt et al., 2005; Bouwer and Aerts, 2006). The paper in this way contributes to the discussions on a post-2012 climate regime.

The aim of a mainstreaming strategy, as part of climate policies, is to capture the potential in other policy areas and sectors for implementing climate-friendly and climate-safe development pathways (Munasinghe, 2002). It would help to enhance the climate change regime by increasing policy coherence, minimising duplications and contradictory policies, dealing with trade offs and capturing the opportunities for synergistic results in terms of increased adaptive capacity and lower emissions. It may also help to make climate change policies more acceptable to both industrialised and developing countries (Davidson et al., 2003; Gupta, 1998; Gupta and Hisschemöller, 1997). The importance that countries for example attach to health and air quality can result in addressing climate change indirectly, but only if these policy activities are well aligned.

It is however also clear that a mainstreaming strategy comes with challenges of its own. We identify four main problems. Firstly, during recent decades, the number of international (environmental) treaties and the institutional density on the international level increased dramatically. This has taken up a large part of the political manoeuvring space. Given the existence of different regimes, with their own rules, dynamics, culture and ambitions, improving policy coherence and mainstreaming climate change into them may lead to friction. Climate change is often only one of many issues that need to be addressed and a risk of mainstreaming overload arises. Secondly, existing international policy frameworks are usually not designed to promote mainstreaming and the organisational structures with their vested interests complicate this further. This often results in a lack of cooperation, coordination and joint decision-making on different levels, hindering any mainstreaming strategy. Thirdly, there is the issue of communication and understanding. Different communities operate on different spatial and time scales, have different priorities and speak different languages. This is especially the case for climate change: a long-term problem characterised by intrinsic uncertainties. And fourthly, it needs to be acknowledged that climate change is not always synergetic with other policy areas. Between climate change and energy security of supply for example, clear trade-offs can be identified for coal-producing countries. Improving on institutional inter-linkages help dealing with these trade-offs (OECD, 2005; Kok et al., 2006).

This paper aims to strike a balance between the opportunities and limitations that a mainstreaming strategy has on offer for future climate policies. In the analysis, a distinction is made between climate change adaptation (Section 3) and mitigation (Section 4), as the interactions are notably different for both elements of climate policy. In these sections, the following issues are subsequently addressed. It starts with an analysis of what the potential synergies and trade-offs between climate change and other policy areas are. Although in some areas, modelling exercises are available to arrive at quantitative estimates of synergies (particularly in the field of air quality and climate change mitigation) in most there is insufficient quantitative information to pursue the same level of precision. Subsequently, we identify policy options for mainstreaming. Although, we recommend directions for mainstreaming, to go deeply into this for every policy area is beyond the scope of this paper. This has two main reasons. The paper would become overly expansive and the general message, that there is a considerable underused cost-effective potential for climate change mitigation and adaptation that can be exploited through mainstreaming, would be lost in detail. Furthermore, in mitigation but particularly in adaptation, it is highly context dependent, whether a particular recommendation can be carried out and would be effective. To conclude, this paper suggests ways forward on the institutional level to make better use of the possible synergies between climate change and the other areas (Section 5), and ends with a discussion of the conclusions (Section 6).

\section{Approach}

The approach in this paper is to start from development and societal priorities of countries and sectors to identify opportunities for widening the scope of climate change policy. So, this paper looks for opportunities realising such primary objectives as poverty alleviation, improving health, food and energy security, while also realising climate benefits. By aligning development and climate objectives, mainstreaming climate change adaptation and/or mitigation can help to "make development more sustainable" (Davidson et al., 2003). From a climate change perspective, this means development that reduces vulnerability to climate change impacts (adaptation) and/or development with lower greenhouse gas emissions (mitigation). Earlier analysis has reviewed the existing literature on the potential for this in a number of policy areas (Kok and de Coninck, 2004). This paper summarises the main findings and brings them together in a coherent framework to discuss the potential of a mainstreaming strategy as part of the effort to combat climate change.

As a first step, this paper explores the potential for mainstreaming climate in other policy areas, by looking at the material (or factual) inter-linkages. Material inter-linkages are inherent physical connections between policy domains. Analysing material inter-linkages helps to identify the potential of enhancing collaboration between different issues because of the way they interconnect. Material inter-linkages between air quality and climate change are for instance, that ozone is both an air pollutant and a greenhouse gas or that certain air pollutants can be chemical precursors for greenhouse gases. In the second step possible measures are identified that either are synergetic or result in trade offs between 
Table 1 - Policy areas for which this paper examines the possibilities for mainstreaming climate change adaptation and mitigation
Adaptation

Poverty reduction

Rural development and agriculture

Disaster management

\section{Mitigation}

Energy security of supply Air quality and health Trade and finance different policy goals. A possible measure may, for example, be to increase the use of domestic coal, without applying carbon dioxide capture and storage. In that case, the energy security situation of a country may be improved, but the climate change problem is worsened. In the third step possible policy options for mainstreaming climate adaptation and mitigation in these other policy areas are analysed.

Table 1 provides an overview of the policy areas for which this paper explores the possibilities for mainstreaming climate change adaptation and mitigation. This selection is not meant to be exhaustive for all areas that interact with climate change, but provides an overview of some the most relevant policy areas to look at. Other possible policy areas to look at would include water (see for example, Co-operative programme on Water and Climate, 2006) and forestry (see for example, Trines et al., 2006).

The last part of this paper considers the institutional and organisational inter-linkages that are necessary to capture the potential identified. These are connections between different institutions that rule a specific policy domain and/or the organisations that are active in that domain. By looking at this, it is possible to examine whether different institutions and organisations are compatible, synergetic, incompatible or contradictory. This helps to identify ways in which the combined impacts of institutions and organisations can be enhanced (Asselt et al., 2005). The assumption is that also on the institutional and organisational level changes need to take place before the policy options for mainstreaming can be implemented effectively. Although this needs to start within countries, this paper will focus on the level of international institutions that have to provide the conditions that enhance national implementation.

\section{Widening climate change adaptation efforts}

Adaptation to climate change comprises all efforts to reduce vulnerability to the impacts of climate change (IPCC, 2001b). Vulnerability is a function of exposure, sensitivity to impacts and the inability to cope or to adapt. This section discusses the material inter-linkages, possible measures and policy options for mainstreaming climate adaptation in poverty reduction, rural development and agriculture, and disaster management.

\subsection{Material inter-linkages with climate change adaptation}

Strong material linkages exist between climate change adaptation and poverty reduction, rural development and agriculture, and disaster management. These linkages come about through the following characteristics of impacts of climate change, that: (a) will likely be highest in developing countries; (b) would be severest for sectors that are highly climate-dependent, notably agriculture; (c) are likely to hit the poorest part of the populations most as they are less able to cope or to adapt.

Poverty reduction and the fight against hunger and malnutrition are the highest priorities on the (international) development agenda. In many developing regions, natural resources are especially relevant as a means to lift the rural poor above the poverty line, focusing attention on rural development (Millennium Ecosystem Assessment, 2005). In 2000, all 191 UN States agreed to halve poverty and hunger by 2015 in the Millennium Development Goals (MDGs) (Millennium Declaration, 2000). In 2000, about 1.1 billion people (or $23 \%$ of the total population of developing countries) lived on less than US $\$ 1$ a day (UNDP, 2004). It is, however, increasingly recognised that meeting development goals, including the MDGs, will become more difficult as a result of climate-change impacts (DFID, 2002; UN Millennium Project, 2005). Climate change will for example reduce economic growth, threaten investments and lower food production, and these impacts will be felt most strongly by the poor.

FAO's latest estimates (1997-1999) indicate a total of 815 million undernourished people in the world of which 777 million in the developing countries. For the developing countries, the latest figure represents a decrease of 39 million since 1990-1992 (the benchmark period used at the World Food Summit in 1996 (FAO, 2005)). Climate change is starting to become an additional stress factor for agricultural production, having a negative impact on the productivity of the land, especially in low-latitude countries (Mendelsohn et al., 2006). In developing countries, many people are directly dependent on the natural resource base for food production and other services, either for subsistence or for income through selling of agricultural products. Agriculture has always been one of the most climate-sensitive economic sectors. Some $40 \%$ of the world's land area is located in environments which are prone to water scarcity (Kabat and Van Schaik, 2003), most of them in developing countries. The major characteristic of these land areas, often denoted as "drylands", is the extreme spatial and temporal variability of precipitation.

Societies evolving in these environments have, over the centuries, developed a broad range of mechanisms to cope with climate variability (Falkenmark and Rockström, 1993; Leisinger et al., 1995; Dietz et al., 2004). These mechanisms are increasingly challenged as traditional weather patterns are changing and the number of reported climate-related disasters is rising rapidly. Although currently the cause for this trend cannot be attributed to climate change, and much of the rise is probably due to population growth, particularly in coastal areas, and improvements in reporting, it is likely that climate change will reinforce the trend towards more frequent, more severe and more costly climatic disasters (IPCC, 2001b; van Aalst, 2006).

\subsection{Possible measures}

Offering economically viable opportunities for the sustainable management of natural resources needs to be at the core of 
any rural development planning. Economic development of the poor is necessary to provide income to decrease their vulnerability and to empower them to cope with the impacts of climate change. It is at the same time also clear that natural resources alone often do not provide sufficient income and employment opportunities in rural areas to support sustainable forms of development to all (Heemst and Bayangos, 2004; Verhagen et al., 2004). The measures identified can be grouped in resource management for sustainable land-use, specific activities aimed at rural and agricultural development and specific measures for climate proofing agricultural practice, also taking into account a future increase in climate related disasters. Implementation of these measures can be stimulated through policies taken in the three areas addressed in the previous section.

Over the last decades food production has more than kept pace with global population growth. This has mainly been achieved through agricultural intensification. In order to increase production per hectare (Evans, 1998), the global irrigated area has increased and the use of purchased inputs (e.g. fertilisers) and new technologies has grown. The expansion of agricultural land has slowed down over the last few decades. Changing consumption patterns and diets have caused the increase in cereal production to slow down, but the quantity of livestock products to rise (Delgado et al., 1999).

In general, increased food production has come at a cost. Natural resources, in particular soil and water, are overexploited. This undermines the very base of these production systems via erosion and soil fertility loss, and reductions in water quality and quantity. Sustainable land use depends on maintaining environmental functions such as water supply, biodiversity and carbon stocks. It is possible to increase food production in an environmentally sustainable way while at the same time avoiding overexploitation and vulnerability to climate change. Good management of the natural resource bases (including agricultural production) takes into account the different social, economic and environmental concerns that are important from a sustainable development perspective. This requires an integrated and synergistic resource management approach that embraces locally appropriate combinations of livelihood strategies for farm households (Dixon et al., 2001). The exact measures will differ per area and crop, and it goes beyond the scope of this paper to detail them further (see Verhagen et al., 2004).

Activities crucial to boosting development in rural areas include increased agricultural production, small-scale industrial enterprises and tourism. Non-food crops with added value such as energy and raw materials are also interesting options. Depending on local resources and price levels, this could open up new opportunities for rural development. The production of non-food crops, for example, for industrial processes and as bio-fuels, would create new options for farmers as long as this fits in sustainable land use and, notably, does not occur at the expense of pristine areas. The substitution of fossil fuels would also lead to reduced emissions of greenhouse gases and positive linkages with mitigation (see Section 4 of this paper). It is interesting to note that economic development, reducing vulnerability, and climate change mitigation can come together this way, provided that small-scale farmers will benefit from these new opportunities (ENDA et al., 2006). If the world moves towards a bio-based economy, the area cultivated with nonfood crops can increase dramatically. As with other cash crops, competition for land with food crops will be a concern for food-insecure areas.

Measures for sustainable resource management and rural development can make a contribution to disaster risk management. Risk prevention is highly synergetic with climate adaptation measures (Sperling and Szekely, 2005). Often in early warning, rural planning, and other information systems, the present climate variability is taken as the benchmark. Incorporating possible future climate changes will be increasingly possible as regional and local projections for climate change patterns improve and contribute to better preparedness.

Addressing the trade-offs between climate change impacts and the other policy areas to avoid mal-adaptation could be defined as a "minimal approach". Such an approach would screen measures on their climate resilience, and only allow those that are minimally vulnerable to a changing climate, and to minimise future negative impacts of climate change by climate proofing agriculture. A "maximal approach" would expand on the minimal approach by trying to achieve multiple dividends and potential synergies in the field of poverty reduction, agricultural production and disaster reduction and climate change. This would yield a basket of measures, including resource management for sustainable land-use, specific activities aimed at rural and agricultural development, and non-food use of biomass.

\subsection{Policy options for mainstreaming}

The previous section has identified measures that make livelihoods more sustainable, while also reducing the vulnerability to climate change impacts. This section provides an overview of polices for international organisations that offer opportunities for mainstreaming adaptation to climate change in these policy areas.

The need for mainstreaming climate change adaptation in development planning and cooperation is increasingly recognised. This is for example illustrated by the declaration of development and environment ministers of OECD countries (OECD, 2006), that states that OECD-countries will work to better integrate climate change adaptation in development planning and assistance. The 2007 EU Green paper on options for EU action identifies integration of adaptation into EU external relations as an important pillar of its work (European Commission, 2007). As a significant part of development assistance is directed at activities that are potentially affected by climate change (OECD, 2005). There is a whole suite of policy frameworks for development planning and development cooperation that currently hardly pay any attention to climate change risks (OECD, 2005) and in which climate change adaptation can be mainstreamed at the project, national or sectoral level. An example is the process leading to Poverty Reduction Strategies Papers (PRSPs).

The PRSP process is relatively new and still evolving. Various reviews have noted the opportunity to influence the process leading to a PRSP, emphasise them as mechanisms for mainstreaming climate change policies and strategies as well 
as the need to go beyond the national level and integrate climate adaptation into local-level planning and implementation (VARG, 2003; Eriksen and Naess, 2003; Agrawala and Berg, 2002), following the extensive decentralisation processes that are taking place in many developing countries. Reviews of the integration of environmental concerns in PRSPs conclude however that many PRSPs pay little to very little attention to basic issues of environmental health, natural resource degradation and vulnerability to environmental hazards (Bojo and Reddy, 2002). This is consistent with a review of countrylevel progress on the implementation of the seventh MDG, on ensuring environmental sustainability that shows that environmental issues do not receive much attention outside of MDG 7 (Lee and Ghamine, 2005). Yet, reviews also state that positive examples exist. There are several examples of PRSPs providing promising links, for example in the case of Tanzania (Mwandosya, 2006). These examples clearly deserve a following and could be put forward as "best practices" to enhance up-scaling of these experiences.

For vulnerable areas and groups, additional efforts will be necessary to adapt to changes in climatic conditions. Relevant agricultural decisions are taken mainly at the local and national level, but international policies also influence these choices. Organisations like the Food and Agriculture Organisation (FAO) and the Consultative Group on International Agricultural Research (CGIAR) can guide local and national decisions by showing best practices and by helping to improve (sub-)national policy frameworks.

Increasingly, the links between vulnerability for disasters and climate change adaptation are acknowledged in the development and international aid communities, and some governments have even formulated policy objectives to integrate disaster reduction in poverty reduction policies (DFID, 2006; Schipper and Pelling, in press). Development policies would provide the framework that can bring disaster reduction and climate change adaptation together and strengthen both (Sperling and Szekely, 2005). Measures may be most effective if they are structurally applied in "natural disaster hotspots" (Dilley et al., in press). Examples of policies that can be undertaken by donors to support countries to mainstream disaster reduction and adaptation in development planning include: (a) support for improving government response capacity as part of sustainable development policies; (b) support for provision of information and capacity to the most disaster-prone regions and communities to leave them more prepared (especially those recovering from earlier shocks); (c) support for making disaster preparedness part of the national development planning; (d) support for early warning systems and capacity in responding to disasters; (e) encouraging affected governments to take a more systematic approach to disaster preparedness.

The importance of structural conditions that determine the vulnerability of farmers, although not directly linked to climate change adaptation policies, is illustrated by the fact that farmers and countries that depend on commodity exports could benefit from changes in agricultural subsidy policies. Subsidy-reform would allow farmers to strengthen their position in the market and invest in development of the sector, thus reducing farmers' vulnerability.
Based on the above, Table 2 provides an overview of policy options for mainstreaming climate change adaptation. These policy actions are not very specifically elaborated as adaptation efforts are intrinsically local in nature and implementation is context dependent.

\section{Widening climate change mitigation efforts}

Mitigation of climate change includes all anthropogenic efforts that reduce greenhouse gas emissions or enhance their sinks (IPCC, 2001a). Greenhouse gas emissions arise from almost every thinkable economic activity through the use of fossil fuel-based energy or changes in land use. This section will discuss the material inter-linkages, possible measures and policy options for mainstreaming climate change mitigation in security of energy supply, air pollution and health, and trade and finance.

\subsection{Material inter-linkages with climate change mitigation}

Security of energy supply is an important priority for energy import-dependent countries. In most countries, the reliance on imported energy is expected to increase over the next decades (IEA, 2005); for the European Union, for instance, the self-sufficiency is expected to decrease from around 55\% in 2000 to $30 \%$ in 2030 (European Commission, 2006). The principal aim of energy security policies is to ensure the reliable supply of affordable energy. Currently, the most used and cheapest energy source is fossil fuels, and because of rising oil and gas prices, particularly coal is on the rise. The main material linkage between security of energy supply and climate change relates to the greenhouse gas emissions resulting from the dominant use of fossil fuels in our energy system. IEA (2007) distinguishes four areas of energy insecurity, of which "concentration of fossil fuel resources" is the one most pertaining to climate change, as means to address it "include moving away from fossil fuels". Tension between the rising energy demand and the limited number of countries that control the available resources on the one hand, and the need to reduce $\mathrm{CO}_{2}$ emissions on the other, is growing. While reducing dependence on imported energy is a key objective in most countries and clear synergies with climate change mitigation are possible, the benefits of increased use of domestic energy carriers is rarely accounted for (Egging and Oostvoorn, 2004).

Air pollution is a severe cause of health problems in both developing and industrialised countries, and in all countries alike; policies are developed to address it. Research on air pollution and health shows that there is a large potential for synergies between air pollution and climate change policy, especially in the technological measures taken to abate both (Alcamo et al., 2002; Syri et al., 2001). The material interlinkages between air quality and climate change are diverse. Firstly, air pollution and greenhouse gases share the same atmosphere, which enables physical interaction and therefore creates strong material linkages. There are health-affecting air pollutants, notably ozone and soot that are also contributors to climate change. Reduction of atmospheric concentrations 
Table 2 - Policy options for mainstreaming climate change adaptation in poverty reduction, agriculture and land use and disaster reduction

\begin{tabular}{|c|c|c|}
\hline Issue & Area of interaction & $\begin{array}{l}\text { Policy options for mainstreaming climate } \\
\text { change adaptation }\end{array}$ \\
\hline \multirow[t]{3}{*}{ Poverty reduction } & $\begin{array}{l}\text { Synergy: biodiversity and conservation of natural } \\
\text { resources with prevention of land degradation } \\
\text { and climate change adaptation }\end{array}$ & $\begin{array}{l}\text { Payment of the poor for ecosystem services if these lead to } \\
\text { climate change-proof environmental management }\end{array}$ \\
\hline & $\begin{array}{l}\text { Synergy: sustainable livelihoods as an approach } \\
\text { to reducing poverty and dealing with } \\
\text { climate change }\end{array}$ & $\begin{array}{l}\text { Three strategic entry points for adaptation: (1) reduction of } \\
\text { vulnerability of livelihoods, e.g. livelihood diversification; ( } 2 \text { ) } \\
\text { strengthening local capacity and reducing sensitivity; (3) } \\
\text { risk management and early warning }\end{array}$ \\
\hline & $\begin{array}{l}\text { Synergy: poverty reduction strategy papers and } \\
\text { national strategies for sustainable development }\end{array}$ & $\begin{array}{l}\text { Mainstreaming adaptation measures in policy frameworks and } \\
\text { programmes for poverty reduction and sustainable development } \\
\text { mechanisms, using documented "best practices" }\end{array}$ \\
\hline \multirow[t]{4}{*}{ Agriculture } & Synergy: drought resistance & $\begin{array}{l}\text { Increased water use efficiency, improved soil crop management, } \\
\text { insurance }\end{array}$ \\
\hline & $\begin{array}{l}\text { Synergy: more efficient use of inputs (nutrients } \\
\text { and water) }\end{array}$ & Precision agriculture, improved soil and crop management \\
\hline & $\begin{array}{l}\text { Synergy: more resistance against pests and } \\
\text { diseases }\end{array}$ & Climate change resilient crops, insurance \\
\hline & Synergy: dealing with climate variability & $\begin{array}{l}\text { Early warning systems, also helpful in dealing with climate } \\
\text { change }\end{array}$ \\
\hline Soils and sinks & $\begin{array}{l}\text { Synergy: combating land degradation, } \\
\text { overexploitation }\end{array}$ & $\begin{array}{l}\text { Intensification of agriculture, freeing land for carbon } \\
\text { management. } \\
\text { Extensification: enhancing carbon management, zero tillage }\end{array}$ \\
\hline Disaster reduction & $\begin{array}{l}\text { Synergy: effects of flooding in degraded and } \\
\text { deforested areas } \\
\text { Synergy: drought prevention } \\
\text { Synergy: natural disaster risk reduction; } \\
\text { increasing resilience to floods and droughts }\end{array}$ & $\begin{array}{l}\text { Arrange landscape planning to minimise the effects of } \\
\text { flash floods } \\
\text { Early warning systems aimed at land managers } \\
\text { Landscape planning and (micro-)insurance }\end{array}$ \\
\hline Subsidies & $\begin{array}{l}\text { Trade-off: current agricultural subsidy regime } \\
\text { is not enhancing resilience or sustainable } \\
\text { land use }\end{array}$ & $\begin{array}{l}\text { Moving subsidies moving towards rewarding farmers for } \\
\text { sustainable land use (reduces their vulnerability) }\end{array}$ \\
\hline
\end{tabular}

of these substances automatically has a double effect as it reduces air pollution and mitigates climate change. In addition, there are indirect effects of air pollutants on climate change and vice versa. For instance, emissions of sulphur oxides, which lead to inter alia acid rain, also enhance formation of sulphate aerosols, which have a short-term cooling effect. It has been emphasised that the reductions in sulphur emissions for the sake of air pollution control may lead to enhanced-climate change (e.g., Stanhill and Cohen, 2001; Wild et al., in press), and even that sulphur can be deliberately emitted to mitigate climate change (Wigley, 2006; Crutzen, 2006). Secondly, air pollution is often caused by activities that also produce greenhouse gas emissions, such as industrial production, electricity generation and transport (Sliggers, 2004).

The interactions between trade and finance and climate change mitigation take place in different ways. Trade liberalisation policies usually increase economic activity, and hence, greenhouse gas emissions. On the other hand, climate policy may have an impact on trade flows by affecting the competitiveness of countries, or may lead to innovation and diffusion of new technologies, in turn opening greenhouse gas abatement opportunities (Charnovitz, 2003). Direct and indirect subsidies on fossil fuels are important policy disturbances that artificially reduce prices of fossil fuelled energy and affect climate change in two ways. In the first place, artificially lowered prices lead to more consumption and hence green- house gas-intensive trade and production. Secondly, these subsidies also artificially increase the relative prices of alternative energy options, such as renewable energy (Beers, 2004).

\subsection{Possible measures}

Measures that meet the objectives of energy security policies as well as mitigation of climate change are ample (Holdren and Smith, 2000). For example, energy efficiency measures can be implemented against low cost, but are difficult to implement because of a variety of social and system limitations (Shove et al., 1998). Renewable energy use in the transport sector because of its almost-exclusive oil dependence the sector most susceptible to security of supply problems - is an area where many opportunities have been identified, but costs are often higher than the costs of conventional oil, and the largescale cultivation of bio-energy crops may lead to deforestation and food security problems. In the heating and electricity sector, synergetic measures can be identified, as well as tradeoffs. The use of renewable fuels or nuclear can lead to lower energy imports and reduce greenhouse gas emissions, but switching to coal to reduce dependence on oil or gas will increase $\mathrm{CO}_{2}$ emissions, provided $\mathrm{CO}_{2}$ capture and storage is not applied.

Air quality improvements and climate change can be synergetic when the use of fossil fuels is addressed (Rabl and 
Dreicer, 2002). This means that either the use of fossil fuel is made more energy-efficient or is avoided through the switch to renewable and nuclear energy. This can be done in the energy sector, in industry, households and in transport. In addition, to address air quality alone, end-of-pipe technologies can be used. However, these have a negative effect on climate change, as they tend to decrease plant efficiency and increase its carbon intensity. The use of sustainably grown biomass, which is good for climate change, may be bad for air quality if the flue gases are left untreated (Bakker et al., 2004).

Table 3 gives an overview of the main interactions of the measures identified. Many measures are related to the energy sector and address the fuel mix in particular. The most promising options are those with synergies in climate change, air quality and security of energy supply. A "+" indicates a synergy between the measure and the policy field of climate change, air quality or security of energy supply; a "-_" indicates a trade-off. " 0 " indicates that no interaction in particular can be discerned. A " \pm " indicates that the effect can be positive in some regions and negative in others, depending on the circumstances. The options that have a "+" in one of the columns, and a "-" in one of the others may signal trade-offs that need to be addressed.

Table 3 shows that synergies between the three issue areas can be realised by using the right technologies. Examples of potentially promising options are improving energy efficiency and low-carbon energy sources (which both address climate change and air pollution), along with ensuring energy supply security by: (1) focusing on domestically available resources and making domestic reserves or (2) focussing on supply of fuels that have a wide geographical spread in countries that are not or less susceptible to political turmoil. More lowcarbon energy sources can be achieved by shifting from oil to gas, bio-fuels or hydrogen in the transport sector and deployment of renewable and nuclear energy.

Addressing the trade-offs between climate change mitigation and the other policy areas could be defined as a "minimal approach". Such an approach would be aimed at minimising the negative impacts of non-climate policy developments on climate change. The mix of policies and measures comes into play on a global level or in countries crucial to climate negotiations, and involve four crucial components: "greening" of investments in the energy sector; phase-out of subsidies on fossil fuels; addressing the vested interests in fossil fuels; and using clean coal technologies to meet the growth in large developing countries through technological cooperation or mandatory international technology-oriented agreements (de Coninck et al., 2007).

A "maximal approach" would achieve the above goals, extended with policies and measures that can be undertaken in the field of climate change mitigation, reduction of air pollution, and security of energy supply, yielding a basket of measures that have a "triple dividend" and use the potential synergies. These measures include energy conservation; a fuel switch to

Table 3 - Inter-linkages between measures dealing with air pollution, security of energy supply and climate change mitigation

\begin{tabular}{|c|c|c|c|}
\hline Measures & Air quality & $\begin{array}{c}\text { Security of } \\
\text { energy supply }\end{array}$ & $\begin{array}{l}\text { Climate change } \\
\text { mitigation }\end{array}$ \\
\hline \multicolumn{4}{|l|}{ Electricity production ${ }^{\mathrm{a}}$} \\
\hline Conversion of efficiency improvement & + & + & + \\
\hline \multicolumn{4}{|l|}{ Renewable electricity ${ }^{\mathrm{a}}$} \\
\hline Photovoltaic & + & \pm & + \\
\hline Wind energy & + & \pm & + \\
\hline Biomass & $0 /-$ & + & + \\
\hline Hydro & + & \pm & + \\
\hline Nuclear & + & + & + \\
\hline Fuel switch for coal $\rightarrow$ gas & + & - & \pm \\
\hline More use of coal & - & + & - \\
\hline More use of coal, but combined with $\mathrm{CO}_{2}$ capture and storage & $+/ 0$ & + & + \\
\hline \multicolumn{4}{|l|}{ Transport $^{\mathrm{a}}$} \\
\hline Hybrid electric cars & + & + & + \\
\hline Fuel cell technology & + & + & + \\
\hline Fuel efficiency & + & + & + \\
\hline Fuel switch for petrol $\rightarrow$ diesel & - & 0 & + \\
\hline Coal to liquids & - & + & - \\
\hline \multicolumn{4}{|l|}{ Industry ${ }^{\mathrm{a}}$} \\
\hline Energy efficiency & + & + & + \\
\hline Material efficiency & + & + & + \\
\hline Air pollutant scrubbers & + & $0 /-$ & - \\
\hline \multicolumn{4}{|l|}{ Household ${ }^{a}$} \\
\hline Fuel switch for local heating and cooking & + & - & + \\
\hline Efficient cook stoves & + & + & + \\
\hline Solar home systems for lighting & + & + & + \\
\hline
\end{tabular}


Table 4 - Policy options, and relevant countries and regions, for integrating climate change mitigation concerns in security of energy supply, air quality and health, and trade and finance

\begin{tabular}{|c|c|c|c|}
\hline Issue & Area of interaction & $\begin{array}{l}\text { Relevant countries } \\
\text { or regions }\end{array}$ & $\begin{array}{l}\text { Policy options for mainstreaming } \\
\text { climate change mitigation }\end{array}$ \\
\hline \multirow[t]{4}{*}{ Security of energy supply } & Synergy: more efficient use of energy & Global & $\begin{array}{l}\text { Energy-saving policies to reduce } \\
\text { demand }\end{array}$ \\
\hline & $\begin{array}{l}\text { Trade-off: use of coal to meet } \\
\text { increasing energy demand }\end{array}$ & $\begin{array}{l}\text { India and China, } \\
\text { in particular }\end{array}$ & $\begin{array}{l}\text { Policy package for more efficient } \\
\text { and cleaner fossil fuel use and } \\
\text { incentives for development of } \\
\text { new low- } \mathrm{CO}_{2} \text { coal technologies }\end{array}$ \\
\hline & $\begin{array}{l}\text { Synergy: reduced use of fossil fuels } \\
\text { through use of renewable and } \\
\text { nuclear energy and other fuels }\end{array}$ & $\begin{array}{l}\text { Energy-dependent } \\
\text { countries with much } \\
\text { potential for renewable } \\
\text { energy }\end{array}$ & $\begin{array}{l}\text { There are many interests that can } \\
\text { be served by applying renewable } \\
\text { energy sources. E.g., for transport, } \\
\text { fuel switch to gas and in the longer } \\
\text { term to hydrogen is an option, or } \\
\text { more use of biomass. Countries and } \\
\text { parties could be encouraged by } \\
\text { helping them to see the interests }\end{array}$ \\
\hline & $\begin{array}{l}\text { Trade-off: conviction-enhancing } \\
\text { renewables means an economic } \\
\text { threat to energy-exporting regions } \\
\text { in the world. }\end{array}$ & $\begin{array}{l}\text { OPEC, gas-exporting } \\
\text { countries, United States }\end{array}$ & $\begin{array}{l}\text { Technological cooperation in } \\
\text { climate-friendly fossil fuel } \\
\text { applications: fossil based hydrogen, } \\
\mathrm{CO}_{2} \text { capture and storage and clean } \\
\text { fossil fuel technologies }\end{array}$ \\
\hline \multirow[t]{4}{*}{ Air pollution/Health } & $\begin{array}{l}\text { Synergy: urban air pollution } \\
\text { caused by the same activities } \\
\text { as greenhouse gas emissions }\end{array}$ & Global & $\begin{array}{l}\text { Energy conservation in supply } \\
\text { and demand }\end{array}$ \\
\hline & & & $\begin{array}{l}\text { For transport, fuel switch to gas } \\
\text { and, in the longer term, to hydrogen, } \\
\text { mass transit systems and vehicle } \\
\text { maintenance programmes } \\
\text { Decentralised renewable energy } \\
\text { for electricity, cooking and lighting }\end{array}$ \\
\hline & $\begin{array}{l}\text { Synergy: access to modern energy } \\
\text { services in rural areas reduces } \\
\text { indoor air pollution and GHG }\end{array}$ & Developing countries & $\begin{array}{l}\text { Modern energy provision with } \\
\text { renewable energy, more efficient } \\
\text { heating and cooking techniques } \\
\text { and clean fossil fuel use }\end{array}$ \\
\hline & $\begin{array}{l}\text { Synergy: both ozone and soot are } \\
\text { significant air pollutants; both } \\
\text { contribute to climate change }\end{array}$ & Global & $\begin{array}{l}\text { Include ozone and soot in } \\
\text { climate negotiations }\end{array}$ \\
\hline \multirow[t]{2}{*}{ Trade and finance } & $\begin{array}{l}\text { Trade-off: energy subsidies favour } \\
\text { greenhouse-gas emitting activities }\end{array}$ & Global & $\begin{array}{l}\text { Reduction or elimination of } \\
\text { subsidies for fossil fuels, more } \\
\text { subsidies for climate-friendly } \\
\text { energy supply as part of electricity } \\
\text { reform and liberalisation }\end{array}$ \\
\hline & $\begin{array}{l}\text { Trade-off: huge investments still } \\
\text { targeted at fossil fuels }\end{array}$ & Global & $\begin{array}{l}\text { Reducing energy consumption } \\
\text { so less investment is needed } \\
\text { Introducing GHG taxes or border } \\
\text { tax adjustment to favour } \\
\text { climate-friendly investments, } \\
\text { goods and services }\end{array}$ \\
\hline
\end{tabular}

hydrogen in the case of transport; hydrogen generated by coal gasification with $\mathrm{CO}_{2}$ capture and storage; and mass transit systems and vehicle maintenance programmes.

\subsection{Policy options for mainstreaming}

The previous section has identified measures that are synergetic for energy security, air quality and climate change mitigation. This section provides an overview of policies that offer opportunities to mainstream climate into these policy areas.

Regional circumstances affect the available and possible options for integrated security of energy supply and climate change mitigation policies. Many regions can currently not do without fossil fuels to meet their energy demand, so it will be necessary to at least reduce the negative impacts of their use. In addition, several countries are economically dependent on the export of fossil fuels. As indicated above, using technologies that do not compromise the interests of the fossil-fuel exporting countries, such as $\mathrm{CO}_{2}$ capture and storage combined with hydrogen production (allowing for the continued use of gas and coal, and possibly also oil) could prove beneficial for those economies, for energy security of supply and for reducing greenhouse gas emissions. These measures are, however, difficult to realise on an international level in an international agreement, as the security of energy supply is not commonly 
regarded as a collective action problem but as a field where countries simply compete based on price. There is limited cooperation though in alliances such as the European Union or via such organisations as the International Energy Agency. Fossilfuel exporting countries and industrialised fossil-fuel importing countries could make an agreement on transfer of climatefriendly technologies in exchange for fossil fuels supply. Large oil and gas companies could be vehicles for such international technology initiatives, either via principles of corporate social responsibility and voluntary agreements, or enforced by legislative measures on energy efficiency and environment.

Trade policies offer a limited number of opportunities for enhancing climate policy so far. Environmental policies aimed at incorporating the negative environmental external effects of production processes could affect trade flows towards more sustainable production. In terms of financing of projects, mainstreaming mitigation concerns in different financing areas is a considerable opportunity in making investments more sustainable. A significant share of global foreign direct investment is done via multilateral banks, and for example the World Bank is working towards a low-carbon investment framework (World Bank, 2006). In addition to financing, Beers (2004) has identified the area of energy subsidy reform as being crucial for using trade and finance regimes to address climate change mitigation. For example, in the second half of the 1990s, energy subsidy rates of $40 \%$ for coal in China were reported. The subsidy rate of all energy sources taken together is $11 \%$, with both industrialised and developing countries boasting significant subsidy regimes (IEA, 1999). If OECD countries would remove fossil fuel subsidies and assist nonOECD countries in their energy subsidy reform through financial and technology transfers, they could require that non-Annex-I countries accept greenhouse gas obligations as part of the bargain (Beers and Moor, 2001).

International treaties aimed at reducing air pollution are mainly regional, although it is increasingly recognised that air quality is also a global problem (Holloway et al., 2003; Sliggers, 2004). This recognition may generate possibilities for harmonising air pollution measures with climate agreements, in the case that full integration of the policy areas is not feasible. Energy security of supply, conversely, is mainly a national issue, with only some room for bilateral cooperation or cooperation in the context of, for example, the European Union. Policy harmonisation both ways (energy security in climate policy as well as vice versa) would be difficult here because of the different policymaking levels. Mainstreaming with respect to policy options and measures would therefore be relevant here.

Table 4 gives a number of policy options to create synergies between security of supply policies, air quality and health, and climate mitigation. The table points out the countries for which the interactions are most relevant, and further provides information on how climate policy concerns can best be integrated in other policy areas.

\section{Institutional and organisational inter-linkages}

This section examines the institutional and organisational interlinkages to identify ways in which the impacts of international institutions and organisations can be enhanced. International organisations have to satisfy the demand for coordination in areas where the actions of individual countries do not lead to the best outcome for everyone. In trans-boundary environmental issues, international treaties have mushroomed over the past decades (Raustiala and Victor, 2004). The institutional landscape has therefore become increasingly dense and complex, and overlaps are bound to occur. Overlap, in the meaning that an outcome of one treaty has an impact on the outcome of another, can reduce the effectiveness of treaties, but can also be used to mainstream other interests and mobilise synergies. The institutional inter-linkages are discussed simultaneously here for climate change adaptation and mitigation.

There is a long list of relevant institutional and organisational arrangements that could be applied in the different policy areas from the previous two sections. An overview is provided in Table 5. Each of these treaties, organisations or platforms offers opportunities to mainstream climate change adaptation and mitigation. Table 5 also outlines the "windows of opportunity", clearly indicating that work on mainstreaming climate change adaptation and mitigation can start immediately.

The importance of mainstreaming climate is also increasingly recognised amongst the Rio Conventions, as there is a clear convergence of objectives on land use and climate change from the three Rio Conventions, the United Nations Convention to Combat Desertification (UNCCD), the Convention on Biological Diversity (CBD) and the United Nations Framework Convention on Climate Change (UNFCCC), along with the Ramsar Convention and the UN Forum on Forests. The Rio Conventions have set up a Joint Liaison Group to enhance coordination between them. At the individual country level, implementation of the various environmental agreements needs to converge to a greater extent (UNCCD, 2004), as many synergies exist between the different options implemented under the different conventions (CBD, 2003). The Scientific and Technical Advisory Panel (STAP) to the Global Environment Facility (GEF) has designed a tool to improve the inter-linkages in GEF funded projects (STAP, 2004). Moreover, there is a need for parties to focus on an environmental governance framework that links environment with the broader development agenda.

In terms of adaptation, establishing links to risk-management practices in national sectors as well as development assistance by bi- and multi-lateral donor institutions would be among the first on the priority list for mainstreaming climate change adaptation. Although adaptation is essentially a local process, international policies are influencing these local processes and can hence enhance mainstreaming adaptation at the national and local level. The incorporation of climate change risks in the reduction of weather-related natural disasters is already gaining attention (Burton and van Aalst, 2004; van Aalst and Helmer, 2004). Capacity-building of integrated climate risk management can be improved through conventional development assistance and programmes, such as those operated by the UNDP, the International Red Cross, World Bank and bilateral donors. Specific attention has to be paid to mainstreaming climate change in risk management approaches such as Integrated Water Resource Management 
and Integrated Coastal Zone Management, either financed from domestic budgets and/or donor sources. Associated national and multilateral institutions, such as the UN International Strategy for Disaster Reduction, development agencies and NGOs, can already start supporting these linkages.

In the field of mitigation of climate change, efforts are underway to establish links between the WTO and climate change mitigation. These have so far not led to very concrete results. As mentioned, World Bank has developed an investment framework, both to make projects more climate-proof, but also to reduce the greenhouse gas emissions associated with World Bank activities (World Bank, 2006). This could be replicated and institutionalised in other relevant financing institutions, such as the regional development banks. The links with air quality could be addressed through the successful Convention on Long-Range Transboundary Air Pollution (CLRTAP), which in recent meetings has discussed climate change and is looking into the possibility of mainstreaming climate change in its activities, or even including $\mathrm{CO}_{2}$ in its basket of gases. Continuation and deepening of these efforts would be particularly useful as it provides best practices for countries not included in the CLRTAP but interested in reducing air pollution and how to best combine this with climate change mitigation. Institutional linkages between development, climate change and energy security of supply have been firmly established and extensively discussed during the CSD-14 (CSD, 2006). These different agenda's are converging. The follow-up policy-oriented discussions during CSD-15 have however not led to an agreement on how to operationalise the linkages between development, energy security and climate change further. The potential of the CSD to contribute to these issues therefore remains uncertain. A new opportunity arises with the focus of CSD 2008/2009 on agriculture, rural development and land use.

\section{Discussion and conclusions}

Currently, the potential of mainstreaming climate change adaptation and mitigation remains under-exploited. This paper has identified and assessed potential directions to widen the climate regime by mainstreaming climate change adaptation and mitigation in a number of policy areas. Implementing this strategy could enhance the effectiveness and efficiency of the climate regime. As it is clearly going beyond what is currently discussed and agreed upon within the UNFCCC, a mainstreaming strategy would be additional to the climate convention, and should not be seen or pursued as a substitute.

The reasons for seeing mainstreaming as an additional strategy differ for adaptation and mitigation of climate change. With respect to adaptation, there is a risk that the issue gets buried in other agendas, with the result that the climate issue loses attention. Any next UNFCCC agreement therefore needs to be stronger on adaptation to climate change. With respect to mitigation, there is a concern that mainstreaming on its own is unlikely to be environmentally effective, as it will not give certainty on achieving the emission reductions that are required to realise mitigation targets.
One of the advantages of a mainstreaming strategy is that it can be implemented immediately, without a formal connection to the UNFCCC process, and in this way help the climate regime forward at a time that international negotiations on both climate adaptation and mitigation are at a crucial stage. Although the opportunities for mainstreaming climate change are increasingly recognised by analysts, and (inter)national policies are starting to be formulated, implementation is still in its infancy.

With respect to the implementation of mainstreaming climate change adaptation, mainstreaming can be a key component of any national, sectoral or international development framework or project. At the very least, climate change adaptation needs to be mainstreamed in all relevant national and sector planning processes to avoid mal-adaptation that limits realising the specific national and sectoral development goals. Especially in developing countries, this will be of great importance for climate proofing of development planning and assistance.

The institutional embedding for mainstreaming climate change mitigation is likely to differ per related issue. In air quality, for instance, the organisational landscape is relatively clear and linking greenhouse gases with air pollutants seems possible to a certain degree. In energy security of supply, there is much less international coordination, which leads to the recommendation that trade-offs can be prevented by aiming at measures on the technological level, as well as recommending national policies. A minimal approach, addressing the trade-offs only, would already be useful, and is within the scope of what the international community can do.

It is also clear that a mainstreaming strategy has its challenges and this paper has addressed several reasons. Although policy integration is long recognised as a cornerstone for sustainable development, progress has been limited. There is no reason to assume this would be different for mainstreaming climate change adaptation and mitigation. The paper has shown that in different policy domains initiatives start to emerge, but that this still is really only the beginning of a process that needs to be fostered by the international community to become effective. Success will critically depend on further operationalisation at a practical level and up-scaling of these directions for mainstreaming in the specific contexts of each of the policy domains addressed in this paper. Mainstreaming can make an important contribution to addressing climate change, but, to realise any of its potential, requires strong political will and active follow up in implementation.

\section{Acknowledgements}

This research was originally supported by the Netherlands Research Programme on Climate Change, Scientific Assessment and Policy Analysis. The complete report, on which the article is largely based is "Beyond Climate: Options for broadening climate policy" and is available via www.mnp.nl. We thank Harro van Asselt, Stefan Bakker, Cees van Beers, Frank Biermann, Laurens Bouwer, Joyeeta Gupta, Jan van Heemst, Bert Metz, Jan Verhagen and three anonymous reviewers for helpful comments on earlier drafts of this paper. 


\section{R E F E R E N C E S}

Agrawala, S., Berg, M., 2002. Development and Climate Change Project: Concept Paper on Scope and Criteria for Case Study Selection. OECD, Paris.

Alcamo, J., Mayerhofer, P., Guardans, R., van Harmelen, T., van Minnen, J., Onigkeit, J., Posch, M., de Vries, B., 2002. An integrated assessment of regional air pollution and climate change in Europe: findings of the AIR-CLIM Project. Environ. Sci. Policy 5, 257-272.

Aldy, J., Barrett, S., Stavins, R., 2003. Thirteen plus one: a comparison of global climate policy architectures. Climate Policy 3, 373-397.

Bakker, S.J.A., de Coninck, H.C., van Bree, L., Jansen, J.C., 2004. Air pollution, health and climate change: synergies and trade-offs. In: Kok, M.T.J., de Coninck, H.C. (Eds.), 2004. Beyond Climate, Options for Broadening Climate Policy. RIVM report 500019 001/2004.

Barrett, S., 1998. Political economy of the Kyoto protocol. Oxford Rev. Econ. Policy 14 (4), 20-39.

Bojo, J., Reddy, R.C., 2002. Poverty Reduction Strategies and Environment: A Review of 40 Interim and Full Poverty Reduction Strategies. The World Bank, Washington, DC.

Bouwer, L.M., Aerts, J.C.J.H., 2006. Financing climate change adaptation. Disasters 30 (1), 49-63.

Burton, I., van Aalst, M., 2004. Look Before You Leap-A Risk Management Approach for Incorporating Climate Change Adaptation in World Bank Operations. Final Draft prepared for the Global Climate Change Team. The World Bank, Washington, DC.

$\mathrm{CBD}, 2003$. Interlinkages between biological diversity and climate change. CBD Technical Series No. 10, Montreal.

Charnovitz, S., 2003. Trade and climate: potential conflicts and synergies. In: Pew Center, Beyond Kyoto: Advancing the International Effort against Climate Change. Pew Center on Global Climate Change, Washington, DC

Co-operative programme on Water and Climate, 2006. Water and Climate Risks. A Plea for Climate Proofing of Water Development Strategies and Measures. Paper for the World Water Forum, Delft.

Crutzen, P.J., 2006. Albedo enhancement by stratospheric sulfur injections: a contribution to resolve a policy dilemma? Climatic Change 77 (3/4), 211-220.

CSD, 2006. Chair's Summary of the 14th Convention on Sustainable Development.

Davidson, O., Halsnæs, K., Huq, S., Kok, M., Metz, B., Sokona, Y. Verhagen, J., 2003. The development and climate nexus: the case of sub-Saharan Africa. Climate Policy 3 (Supplement 1, November). In: Munasinghe, M., Downing, T.E. (Eds.), Special Supplement on Climate Change and Sustainable Development, pp. 97-113.

de Coninck, H.C., Fischer, C., Newell, R., Ueno, T., 2007. International Technology-oriented Agreements to Address Climate Change. RFF Discussion Paper RFF-DP-06-50.

Delgado, C., Rosegrant, M., Steinfeld, H. Ehui, S., Courbois, C., 1999. Livestock to 2020. The next food revolution. Food, Agriculture and the Environment Discussion Paper 28. IFPRI, Washington D.C.

DFID, 2002. Predicted Impact of Global Climate Change on Poverty and the Sustainable Achievement of the Millennium Development Goals, vol. II. London.

DFID, 2006. Reducing the risk of disasters: Helping to achieve sustainable poverty reduction in a vulnerable world: A DFID policy paper. Available via http://www.reliefweb.int.

Dietz, A.J., Ruben, R., Verhagen, A. (Eds.), 2004. The Impacts of Climate Change on Drylands, with a Focus on West Africa, Kluwer.
Dilley, M., Chen, R.S., Deichmann, U., Lerner-Lam, A.L., Arnold, M., Agwe, J., Buys, P., Kjekstad, O., Lyon, B., Yetman, G., Natural Disaster Hotspots: A Global Risk Analysis. The World Bank Group, Washington, D.C., USA.

Dixon, J., Gulliver, Gibbon, D., 2001. Farming Systems and Poverty. Improving Farmers' Livelihoods in a changing World. FAO and World Bank.

Egging, R., van Oostvoorn, F., 2004. Energy supply security and climate change. In: Kok, M.T.J., de Coninck, H.C., (Eds.), Beyond Climate, Options for broadening climate policy. RIVM report 500019 001/2004.

ENDA, PRI and MNP, 2006. Rural Development and the Role of Food, Water and Biomass: Opportunities and Challenges for Development and Climate. Workshop report, ENDA, Dakar.

Eriksen and Naess, 2003. Pro-Poor Adaptation: Norwegian Development Cooperation and Climate Change Adaptation: An Assessment of Issues, Strategies and Potential Entry Points. Center for International Climate and Environmental Research (CICERO), Report 2003:02, Norway.

European Commission, 2006. Green Paper-A European Strategy for sustainable, competitive and secure energy. Available on: http://ec.europa.eu/energy/green-paper-energy/ index_en.htm.

European Commission, 2007. Adapting to climate change in Europe. Options for EU action. Green paper. Available on: http://ec.europa.eu/environment/climat/home_en.htm.

Evans, L.T., 1998. Feeding the Ten Billion. Plants and Population growth. Cambridge University Press, New York.

Falkenmark, M., Rockström, J., 1993. Curbing rural exodus from tropical drylands. Ambio 22 (7), 427-437.

FAO, 2005. The Statistics Division. http://www.fao.org/es/ess/ mdg_kit/.

Gupta, J., 1998. Leadership in the climate regime: inspiring the commitment of developing countries in the post-Kyoto phase. Rev. Eur. Commun. Int. Environ. Law 7 (2), 178-188.

Gupta, J. Hisschemöller, M., 1997. Issue-linkages: a global strategy towards sustainable development'. Int. Environ. Affairs 9(4), 289.

Heemst, J., Bayangos, V., 2004. Poverty and Climate Change. In: Kok, M.T.J., de Coninck, H.C. (Eds.), 2004. Beyond Climate, Options for Broadening Climate Policy. RIVM report 500019 $001 / 2004$.

Höhne, N., 2005. What is next after the Kyoto Protocol? Assessment of options for international climate policy post 2012, PhD thesis, University of Utrecht, Utrecht, the Netherlands, ISBN 90-739-5893-8.

Holdren, J., Smith, K., 2000. Energy, the environment and health. Chapter 3 of the World Energy Assessment: Energy and the challenge of sustainability.

Holloway, T., Riore, A., Hastings, M.G., 2003. Intercontinental transport of air pollution: will emerging science lead to a new hemispheric treaty? Environ. Sci. Technol. 37, 4535-4542.

Huq, S., Reid, H., 2004. Mainstreaming adaptation in development. IDS Bull. 35 (3), 15-21.

Huq, S., Reid, H., Konate, M., Rahman, A., Sokona, Y., Crick, F., 2004. Mainstreaming adaptation to climate change in least developed countries (LDCs). Climate Policy 4, 25-43.

International Energy Agency (IEA), 1999. Looking at Energy Subsidies: Getting the Prices Right. World Energy Outlook, Paris, France.

International Energy Agency (IEA), 2005. World Energy Outlook. Paris, France.

International Energy Agency (IEA), 2007. Energy security and climate policy. Assessing Interactions. Paris, France.

IPCC, 2001a. Mitigation of Climate Change, Intergovernmental Panel on Climate Change (IPCC) Working Group III, Climate Change 2001. Cambridge University Press, UK.

IPCC, 2001b. Impacts, Adaptation, and Vulnerability. Third Assessment Report, Intergovernmental Panel on Climate 
Change (IPCC) Working Group II, Climate Change 2001. Cambridge University Press, UK.

IPCC, 2007. Climate Change 2007: the physical science basis. Working Group I's contribution to the Fourth Assessment Report. Cambridge University Press, Cambride, UK.

Kabat, P., Van Schaik, H., 2003. Climate Changes the Water Rules: How Water Managers Can Cope with Today's Climate Variability and Tomorrow's Climate Change. Dialogue on Water and Climate, Delft, The Netherlands.

Kok, M.T.J., de Coninck, H.C., 2004. Beyond climate: Synthesis and conclusions. In: Kok, M.T.J., de Coninck, H.C., (Eds.), 2004. Beyond Climate, Options for Broadening Climate Policy. RIVM report 500019 001/2004.

Kok, M.T.J., Metz, B., Verhagen, A., van Rooijen, S.N.M., 2006. Integrated development and climate policies: how to realise benefits at national and international level? Policy Brief, MNP, Bilthoven.

Lee, L., Ghamine, L., 2005. Environmental Sustainability in 100 Millennium Development Goal Country Reports. UNDP, New York.

Leisinger, K.M., Schmitt, K., ISNAR, (Eds.), 1995. Survival in the Sahel, an Ecological and Developmental Challenge. International Service for National Agricultural Research, The Hague.

Mendelsohn, R., Dinar, A., Williams, L., 2006. The distributional impact of climate change on rich and poor countries. Environ. Dev. Econ. 11, 159-178.

Millennium Ecosystem Assessment (MA), 2005. Ecosystems and Human Well-being: Synthesis. Island Press, Washington, DC

Munasinghe, M., 2002. Framework for Analysing the Nexus of Sustainable Development and Climate Change Using the Sustainomics Approach. Paper presented for consideration and review to the participants of the OECD Informal Expert Meeting on Development and Climate Change March 13 and 14, 2002, Paris.

Mwandosya, M., 2006. Mainstreaming environment and climate change concerns in national planning in Tanzania.

Presentation at Development and Climate Workshop, 20-22 September, 2006, Paris.

OECD, 2005. Bridge over Troubled Water. OECD, Paris.

OECD, 2006. Declaration on integrating climate change adaptation into development co-operation. In: Proceedings of the Meeting of the OECD Development Assistance Committee and the Environment Policy Committee, April 4, 2006, OECD, Paris.

Rabl, A., Dreicer, M., 2002. Health and environmental impacts of energy systems. Int. J. Global Energy Issues 18 (2-4).

Raustiala, K., Victor, D.G., 2004. The regime complex for plant genetic resources. Int. Organ. 58, 277-309.

Schipper, L., Pelling, M., Disaster risk, climate change and international development: scope for, and challenges to integration. Disasters 30 (1), 19-38.

Shove, E., Lutzenhiser, L., Guy, S., Hackett, B., Wilhite, H., 1998. Energy and social systems. In: Rayner, S., Malone, E. (Eds.), Human Choice and Climate Change, volume 2: Resources and Technology. Battelle Press, Columbus, OH, USA.

Sliggers, J., 2004. The need for more integrated policy for air quality, acidification and climate change: reactive nitrogen links them all. Environ. Sci. Technol. 7, 47-58.

Sperling, F., Szekely, F., 2005. Disaster risk management in a changing climate. Discussion paper prepared for the World Conference on Disaster reduction on behalf of the vulnerability and adaptation resource group (VARG). Washington DC.

Stanhill, G., Cohen, S., 2001. Global dimming: a review of evidence for a widespread and significant reduction in global radiation with discussion of its probable causes and possible agricultural consequences. Agric. Forest Meteorol. 107 (4), 255-278.
STAP, 2004. A conceptual design tool for exploiting interlinkages between the focal areas of the GEF. GEF, New York.

Syri, S., Amman, M., Capros, P., Mantzos, L., Cofala, J., Kilmont, Z., 2001. Low- $\mathrm{CO}_{2}$ energy pathways and regional air pollution in Europe. Energy Policy 29, 871-884.

Trines, E., et al., 2006. Integrating agriculture, forestry and other land use in future climate regimes. Methodological issues and policy options. WAB 500102 002, Bilthoven.

UN, 2000, Millennium Declaration, New York

UN Millennium Project, 2005. Environment and Human WellBeing: A Practical Strategy. Report of the UN Millennium Project Task Force on Environmental Sustainability, New York, 2005

UNCCD, 2004. http://www.unccd.int/knowledge/menu.php.

UNDP, 2004. Human Development report 2004, New York.

UNFCCC, 1992. Text of the United Nations Framework Convention on Climate Change.

van Aalst, M., 2006. The impacts of climate change on the risk of natural disasters. Disasters 30 (1), 5-18.

van Aalst, M., Helmer, M., 2004. Preparedness for Climate Change. Red Cross/Red Crescent Climate Centre, The Hague.

van Asselt, H.J.M., Gupta, J., Biermann, F., 2005. Advancing the climate agenda: exploiting material and institutional linkages to develop a menu of policy options. RECIEL 14 (3), 255-264.

van Beers, C., 2004. International trade, finance, subsidies and climate. In: Kok, M.T.J., de Coninck, H.C. (Eds.), 2004. Beyond Climate, Options for Broadening Climate Policy. RIVM report 500019 001/2004

van Beers, C., de Moor, A., 2001. Public Subsidies and Policy Failures. Edward Elgar Publishers, Cheltenham, United Kingdom.

VARG, 2003. Poverty and climate change-reducing the vulnerability of the poor through adaptation. Multi-agency (AfDB, ADB, DFID, DGIS, EC, BMZ, OECD, UNDP, UNEP and World Bank) paper, final version, World Bank, Washington, DC.

Verhagen, J., Nabuurs, G.J., Veraart, J., 2004. The role of land use in sustainable development: options and constraints under climate change. In: Kok, M.T.J., de Coninck, H.C., (Eds.), 2004. Beyond Climate, Options for Broadening Climate Policy. RIVM report 500019 001/2004.

Victor, D.G., 2001. The Collapse of the Kyoto Protocol and the Struggle to Slow Global Warming. Princeton University Press, Princeton, NJ.

Wigley, T., 2006. A combined mitigation/geo-engineering approach to climate stabilization. Science 314, 452-454.

Wild, M., Gilgen, H., Roersch, A., Ohmura, A., Long, C.N., Dutton, E.G., Forgan, B., Kallis, A., Russak, V., Tsvetkov, A., in press. From dimming to brightening: decadal changes in solar radiation at earth's surface. Science $308,847-850$.

World Bank, 2006. Investment framework for clean energy and sustainable development. Washington DC.

Marcel Kok has a background in public policy and environmental sciences. He works as a senior policy analyst on global sustainability issues at the Netherlands Environmental Assessment Agency. The main focus of his work is on development and climate issues, vulnerability and governance.

Heleen de Coninck's background is in atmospheric chemistry and climate change. As a scientific researcher at the unit Policy Studies of the Energy research Centre of the Netherlands (ECN), she focuses on international climate policy. She also pursues a $\mathrm{PhD}$ in the field of international technology-oriented agreements for climate change at the Institute of Environmental Studies of the Vrije Universiteit of Amsterdam (IVM). 